\title{
Design Education without Borders: How Students Can Engage with a Socially Conscious Pedagogy as Global Citizens
}

\author{
lain Macdonald and Myrna MacLeod
}

\begin{abstract}
This study examines the student experience of a third sector graphic design project in an international context. Inspired by a humanist and socially conscious perspective that was originally set out by Ken Garland's 'First Things First' manifesto in 1964, the project developed into a collaborative learning experience for African and European students. The aim of this project was to develop student global citizenship and mobility through a cultural learning experience in a very different environment with challenging resources and social conditions. Using student interviews and evidence from their reflective journals, this article analyses how UK design students participated and negotiated the implementation of live projects in an African context, specifically Mozambique. It also examines the wider impact on the cohort of students and friends who did not travel to Africa but followed the experience online. Risk taking, experimentation and an appetite for enquiry are attributes that students are encouraged to develop, but they can equally apply to teachers and lecturers as they develop their curricula. Within the framework of university learning, teaching and assessment strategies space can be found for design educators to look beyond corporate and conventional consumer outlets to a more socially conscious and community focus without borders.
\end{abstract}

\section{KEYWORDS}

graphic design, internationalisation, global citizenship, higher education, post-colonialism

\section{Introduction}

Graphic design education in higher education may be considered to be vocational and focused on teaching a highly technical, particularly digital skill-based curriculum. In a highly competitive higher education environment where there are many courses offering an industry focus and attractive employability prospects, graphic design pedagogy has to look for something different to deliver to students that will make them standout from the crowd.

Risk taking, experimentation and an appetite for enquiry are attributes that students are encouraged to develop (Steers 2009; NSEAD 2014), but they can equally apply to teachers and lecturers as they develop their curricula. Within the framework of university learning, teaching and assessment (LTA) strategies space can be found for design educators to look beyond corporate and conventional consumer outlets to a more socially conscious and community focus without borders.

The aim of this project was to develop student global citizenship and mobility through a cultural learning experience in a very different environment with challenging resources and social conditions. Using student interviews and evidence from their reflective journals this article analyses how UK design students participated and negotiated the implementation of live projects in an African context, specifically Mozambique. It also examines the wider impact on the cohort of students and friends who did not travel to Africa but followed the experience online.

During the four weeks in rural Mozambique the students from a UK university worked alongside local students and in the process developed shared working practices to create branding materials and publicity 
for the SHINE soap cooperative and the LIFE Film Festival. Garland (1964) provides an approach that can culturally inform the European and African students in this study as they actively shape the world around them.

Africa? Would it be safe? Could students spend time in a rural area, working with local people to build brands, without clear and present dangers? A quick search on Google of Mozambique threw up phrases like 'former civil war', 'road issues' and 'occasional kidnappings'. As if a tourist in Japan might decide to avoid the UK based on Google searches throwing up 'Oliver Cromwell' and 'clogged M25'. (MacBeth 2014)

\section{Research context}

In the autumn of 1999, the newly drafted manifesto, 'First Things First 2000', appeared in at least six journals, including Emigre, AIGA Journal of Graphic Design and Adbusters in North America, Eye and Blueprint in the UK, and, on the European Continent, Items (and, much later, Form). It carried Ken Garland's name once more, augmented by those of thirty-two new signatories. In his short article on the history of 'First Things First', Poynor $(1999,56)$ stated:

The vast majority of design projects - and certainly the most lavishly funded and widely disseminated - address corporate needs, a massive over-emphasis on the commercial sector of society, which consumes most of graphic designers' time, skills and creativity.

He thereby made a vital distinction between this singular, commercial role of graphic design and 'the possibility... that design might have broader purposes, potential and meanings'. Katherine McCoy (1994, 111), an American design educator, had earlier expressed the situation thus:

Designers must break out of the obedient, neutral, servant-to-industry mentality, an orientation that was particularly strong in the Reagan/Thatcher 1980s ... Design is not a neutral, value-free process. A design has no more integrity than its purpose or subject matter.

Rawsthorn $(2013,9)$ also argues that 'design' has been 'trivialized, misunderstood and misused', because even before the word 'design' was invented, human beings had sought to change their surroundings instinctively. It was only because of the industrial age that design was redefined as a commercial tool, and is now 'seen as an indulgence for spoilt consumers in developed economies, rather than as a means of helping the disadvantaged out of poverty' (Rawsthorn 2013, 9).

This critical approach to design provides inspiration not only to many contemporary designers, but also educators who seek to challenge global corporate homogenisation and the exploitation of developing countries. As higher education becomes more internationalized, the 'First Things First' manifesto can provide a radical approach to design education in a global context.

The designer is a 'connectivist' with an inherent capacity to establish and foster links between disciplines and cultures. These skills inform how we identify and act upon situations where design can improve the wellbeing of a community, and provide solutions to economic, ecological and cultural sustainability - locally and globally. (Cahalan 2007)

Many UK universities are following the Higher Education Academy (HEA) with strategic plans to make themselves international 'to enhance the student learning experience' (HEA 2008, 6). As economies become 
globally connected there is pressure for higher education to develop student intercultural awareness and global citizenship (Brooks \& Waters 2011; Waters et al. 2011). Alongside the entrepreneurial strategies of governments and education institutions to develop internationalisation, many students are motivated by second chances, fun and excitement as well as the accumulation of cultural capital. Design education can be a transformative and socially engaged practice offering an important platform for student internationalisation (Mendoza \& Matyók 2013).

Rather than an exposure to other cultures, design students need deep immersion in order to 'transform the study abroad tour into a layer of embedded experience rather than an artificial veneer' (Mendoza \& Matyók 2013, 215).

The activities of most cultures are unfathomable, unless they are viewed from within the culture, for membership of a culture provides a set of cultural eyeglasses that are the key to understanding and carrying out its activities. (Brown et al. 1989, 6)

Many academics (Root \& Ngampornchai 2013; Goode 2008; Deardorff 2009) are critical of the impact that such studies abroad claim to have on the student. There is an assumption that immersion in a different culture will automatically lead to intercultural competency (Root \& Ngampornchai 2013). Instead students must first reflect on their own culture and behaviour.

Before students can fully understand aspects of other cultures, it is important for them to explore how much they adhere to cultural norms and values. Without this perspective, students can simply view their culture as the unstated standard by which to perceive and possibly judge others instead of understanding that their cultural background is simply that: a culture which informs their worldviews. (Root \& Ngampornchai 2013, 525)

Intercultural competency requires effective communication with others, the ability to establish relationships and the ability to deal with psychological stress:

Ruben and Kealey (1979) proposed seven behavioral assessments of communicative competency. These include (a) display of respect; (b) interaction posture; (c) orientation to knowledge; (e) empathy; (f) self-oriented role behavior; ( $g$ ) interaction management; and (h) tolerance for ambiguity... Competence, then, is conceptualized based on cognitive (knowledge), affective (attitude and motivation), and behavioral (skills) approaches (Bennett, 2009, Chen, 1990; Howard Hamilton, Richardson, \& Shuford, 1998; Spitzberg, 1989). (Root \& Ngampornchai 2013, 516)

These competencies are essential if graduates, and especially those in design, are to be prepared for global citizenship and design without borders. 'Education plays a vital role in preparing design students to move beyond a purely reactive state to one in which they are actively engaged in shaping the world around them' (Mendoza \& Matyók 2013, 215). International study abroad provides a potentially richer holistic approach to education at a time when higher education has moved towards discipline specific training and job preparation (Mendoza \& Matyók 2013).

Although there is a growing body of academic literature on the internationalisation of higher education, there is still a lack of research on the students' perspective (Brooks \& Waters 2011). This research examined design student experiences working abroad in Mozambique and the perspective of those that remained in the UK who followed their peers via social media. It supports the arguments set out by Mendoza \& Matyók and provides an approach that can culturally inform European and African students as they actively shape the world around them. 


\section{Methodology}

The research methodology sought to reveal how an international project combined with graphic design advocacy could have an educational and cultural impact locally and globally. Globalisation, especially cultural globalisation, deeply influences educational practices (Rizvi 2004). Therefore, research needs to reflect societal or contextual knowledge (Papoutsaki 2006).

In designing the methodology it was important to keep in mind power relations with the participants, which is why the participating students were encouraged to design self-collection instruments to minimise power-dependent relations with the researcher/lecturers that accompanied them (Mertens 2005).

There were two phases to the research. Following university ethical procedures, the five students ( 2 female, 3 male) involved in the Mozambique project were asked in advance to give their informed consent to participate in the study. Qualitative data was generated through reflective logs, a project online blog and in-depth interviews, which were undertaken longitudinally in parallel with the students' study in Mozambique between May and June 2014.

In-depth interviews using a structured questionnaire, taking between 20 to 30 minutes, were conducted on video with the students immediately before their departure from the UK, and a week after their return from Mozambique. During their time abroad the students kept reflective learning logs, and all were encouraged to post on the project's online blog.

A later phase of the research took place five months after the project in Mozambique, just before an exhibition of the project was mounted in the university. The aim was to understand the impact of the project on the home students that remained in the UK - five volunteered to be interviewed.

\section{Reflective and graphic design outputs}

Reflective learning journals are widely used to reflect on the 'encounters' or 'moments' or 'experiences' by briefly recording learning events and then reflect on the meaning of the experience for their own development and learning (Loo \& Thorpe 2002; Wagner 2006). They provide up-to-date reflections on events as they happen rather than retrospectively such as in interviews or questionnaires and give strength to other evidence (quantitative or qualitative).

At the end of their study abroad students were asked to review themselves and what they had recorded in their journals and write and design a book that encompassed a reflection of their learning experience. Through this activity students use their own 'filter' to select the key moments so a student perspective in selecting key points is maintained.

Reflective accounts alone cannot capture the effectiveness of intercultural communication; they can fail to 'connect surface-level cultural norms with deeper values and cultural assumptions' (Root \& Ngampornchai 2013, 524). Design students have the opportunity to communicate visually and creatively in their process and through physical tactile interaction with materials. Observing and repeating techniques, whether with paint and brush or keypad and computer, allows for tacit knowledge and cultural behaviour to be transferred and made explicit.

The prevailing educational culture encourages learning through activity, reflection and conversation (Scottish Funding Council, 2006: 4). These changes also reflect the requirements of commerce and industry, who are demanding graduates with communication, team working and analytical skills (Leckey and McGuigan, 1997, 366; Bryant et al. 2009, 8)

The students participating in this project were able to engage in meaningful design work with local youths, and so out of necessity had to develop communication skills and cultural awareness in order to successfully complete the design tasks in the field. The methodology of documenting this process as it happened was 
by using video and photography. Videography is widely used in the social sciences as a research methodology (Knoblauch et al. 2013).

\section{Data analysis}

The interviews were transcribed and content analysis followed by thematic sampling was conducted on the data from the interviews and reflective journals (Ortlipp 2008). This triangulation of data collection ensured that rich data was obtained and the varied sources of data provided an opportunity to look at the experience from varied angles, both researcher led and student led (Flick 2014).

Student experiences were compared and trends were identified using the themes developing communication skills, intercultural competencies, critical approaches to global consumerism, and views from students that remained home. The students have been anonymised and the students that remained at home have been identified separately.

\section{The project}

It was in October 2013 when third year BDes Graphic Design students at a UK university began working with a German/Mozambican NGO, to design soap packaging and publicity material for a women's co-operative and their other supporting initiative, a new annual film festival. In Mossuril, a poor coastal town in northern Mozambique, a soap co-op has been established to deliver employment for vulnerable women, and improve the hygiene in an area where diarrhoea kills more people than HIV/AIDS, malaria and measles combined.

The class of thirty students participated a two-week project that demanded a quick turnaround and a submission of 3D design prototype packaging artefacts and presentations of branding ideas and how they might be implemented over different media and sites. The brief was given by the charity organisers in a Skype link to the class from their offices abroad in Germany and Mozambique. It was supported by images and video that were posted on the charity website and crowdfunder appeal.

The students, mostly Scottish and many who had not travelled outside the UK, had to rely on these resources and other secondary research to find inspiration to design their soap packaging and film festival branding. At this point of the project any first-hand experience of Africa was unthinkable.

The NGO were so impressed with the selected designs (see Figures 1 and 2) that they felt that the student designers could gain valuable experience by participating in their implementation in Mozambique. What began as an international and intercultural live design brief was now a proposed study of overseas community engagement with design and entrepreneurship as an enhanced student learning experience. Using the leverage of the university strategic plan to encourage student mobility, employability and an enhancing learning experience, the course leader made applications for school and faculty financial support. Applications were invited from the class for four available funded places. The students were then selected on the strength of their work and their personal statements. Four of the five students were university funded (one was self-funded) to allow the project to be set as a credit-bearing module, formalising it into their assessed programme of study.

It is invaluable experience for design students to see their work in production and being implemented, but this was an extraordinary opportunity to participate in international community engagement abroad in Africa. It was hoped that the cultural learning experience in a very different environment with challenging resources and social conditions would develop student global citizenship and mobility.

The NGO saw potential for graphic design and its transformative power to change perceptions and attitudes in a country that is poorly served by the media.

\section{What were the challenges?}

'No one who has lived in the bush takes things for granted again: even little things like turning on a tap or switching on a light remain miraculous' (Teran 2007, 137). 


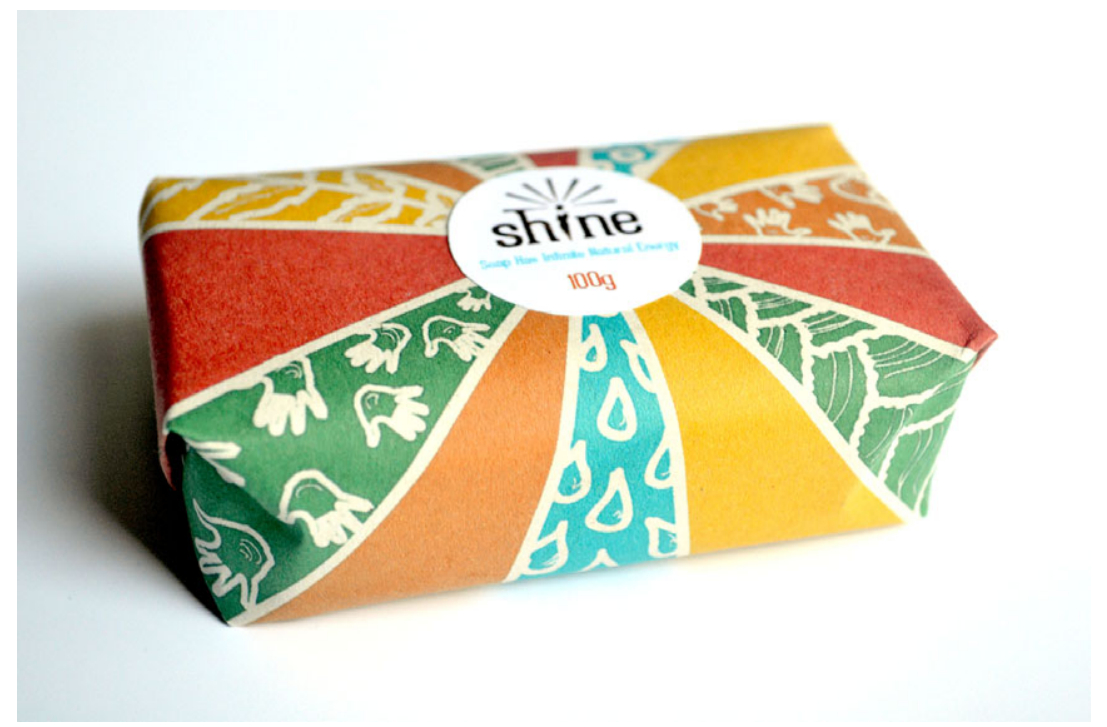

Figure 1. SHINE soap packaging (all Figures used with permission of the authors and students)

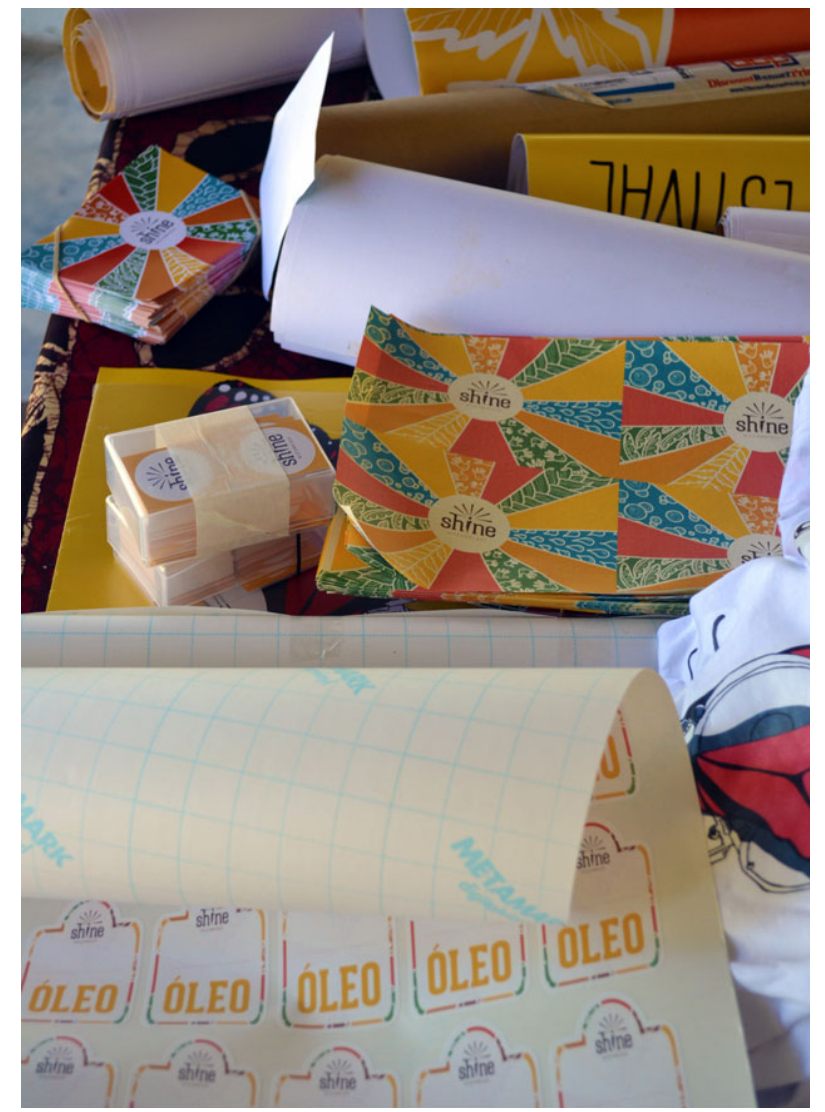

Figure 2. Branding materials from the UK

The students were staying in an eco-tourist lodge that had some basic amenities: comfortable beds with mosquito nets, three meals a day, but water was provided by local children who carried jerry cans up from the well to replenish large bins in their bathrooms (see Figure 3). Any water for consumption (and brushing teeth) had to come from bottled water. 


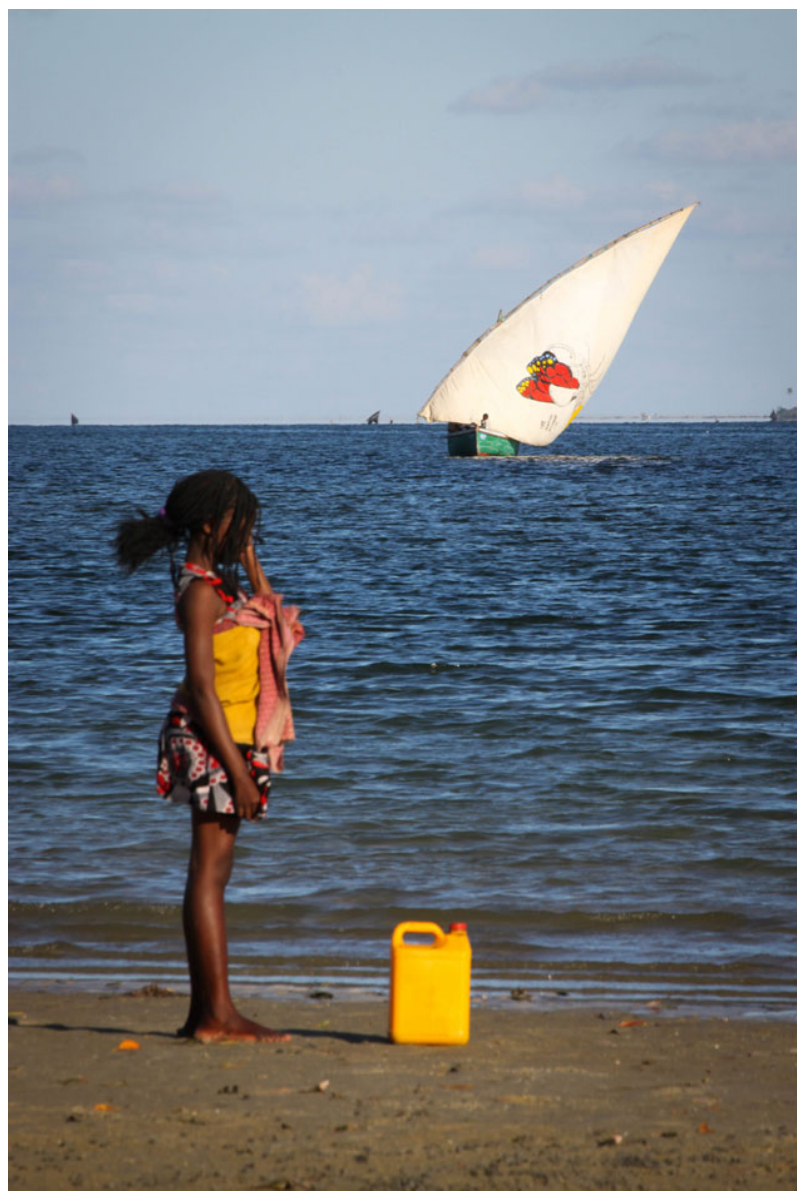

Figure 3. Local girl with water jerry can

At tropical latitudes the day starts and ends early, it is hot and the sun is strong. Managing the work to be completed in the hours of daylight without incurring heat exhaustion was a challenge.

While the students took precautions against malaria, the seriousness of the disease was presented forcefully when the cook, and then a Mozambican student, fell ill during our stay. They recovered, but the wife of another worker died suddenly.

\section{Thematic impact}

In order for students to engage in deep learning from an intercultural experience there needs to be a reflective understanding of their own culture and background (Root \& Ngampornchai 2013). We used video interviews and began personal diaries and a public blog to facilitate this reflective process. However, at the outset it was clear that the students had a range of international experience, with one of them never having left the UK before. As such it was difficult for the students to grasp how their own culture informed their opinion of others. Even after a guest lecture from a Mozambican academic, and researching the Mozambican culture at the start of the design project, it was only on their return that the students understood the difference and value of their own culture and lifestyle (Brown et al. 1989). At the outset they anticipated difference but had no measure of what that would be. 


\section{Developing communication skills}

Before departure, while some of the students were concerned about how they would bridge the language differences, only one took the initiative to learn a little Portuguese. They anticipated that with a slower pace of life it would be something that they could accommodate and find ways of working. However, within their own group dynamic there was concern as to how they would manage to work and live together under the challenging climatic and cultural differences.

Going abroad provides an opportunity to take a different perspective on our daily lives, and the students expected to have space to develop communication skills within themselves. It would give them 'time to reflect'. They wanted the experience to help them 'grow as individuals' and to 'test themselves'. They wanted to develop their independent thinking and self-reliance. It was going to give them more 'confidence', make them 'the person I want to be'.

Once they arrived the short days and limited resources demanded that the students be efficient in their organisation and delegation of tasks: 'we developed patience and communication' (Student R). In an environment with few resources and having to rely on more analogue handcrafts, our students appreciated being out of their comfort zones where they had to learn from each other, especially from one Mozambican student who was a very skilled lettering artist (see Figure 4). They gave each other peer feedback, with the local Portuguese-speaking Mozambique students also adding their friendly critique to the work. 'The trip made me realize that "language" is little more than a hurdle and not a wall like I thought' (Student E). The locals demonstrated to our students how to be resourceful and less inhibited, or as the UK students saw it: 'fearless', whether when working with physical resources or digital software on the laptop computers (see Figure 5). 'During the first week people were quite shy, but we grew in confidence to be more open, yet respectful (with our feedback)' (Student J). This was pivotal moment when the UK students had to reappraise their cultural attitudes as advanced digital designers. The post-colonial inference that they were there to teach the Mozambicans was turned around, the Mozambican students had something of value that the UK students admired culturally.

What impressed the students was the commitment the Mozambican students had for their education. 'They would show up every day, not sure if they understood what was being said, but they were keen to participate and learn English' (Student R). This could be quite flattering if the local cultural norms are not

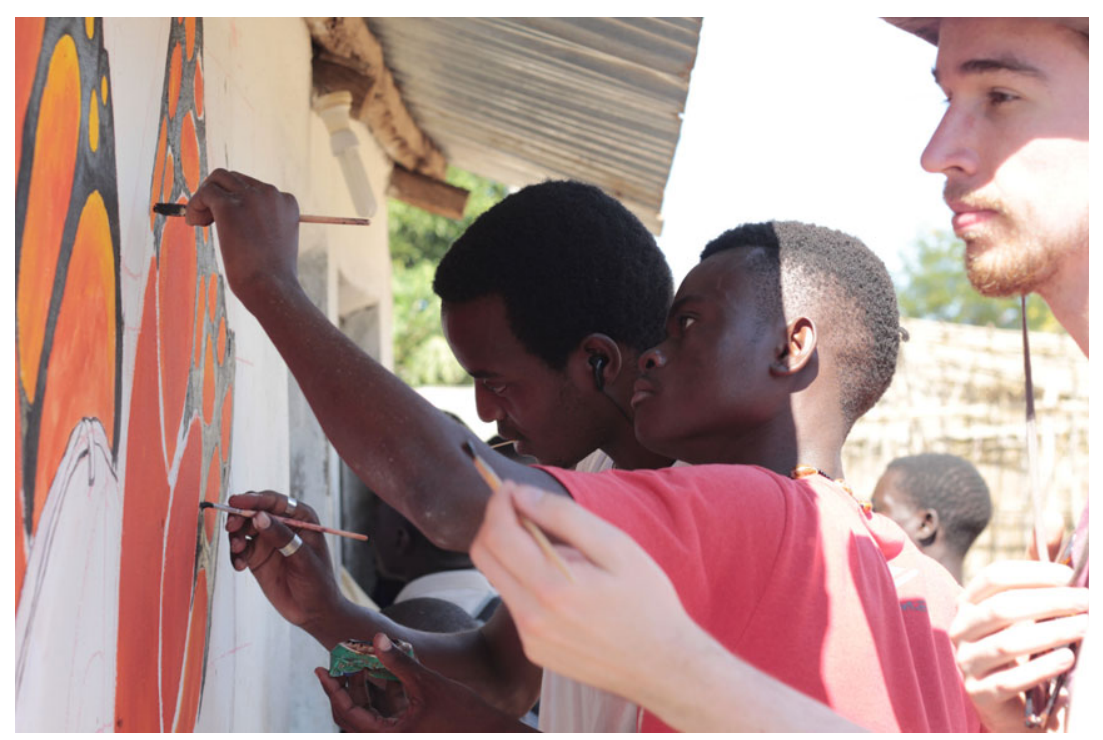

Figure 4. Painting murals 


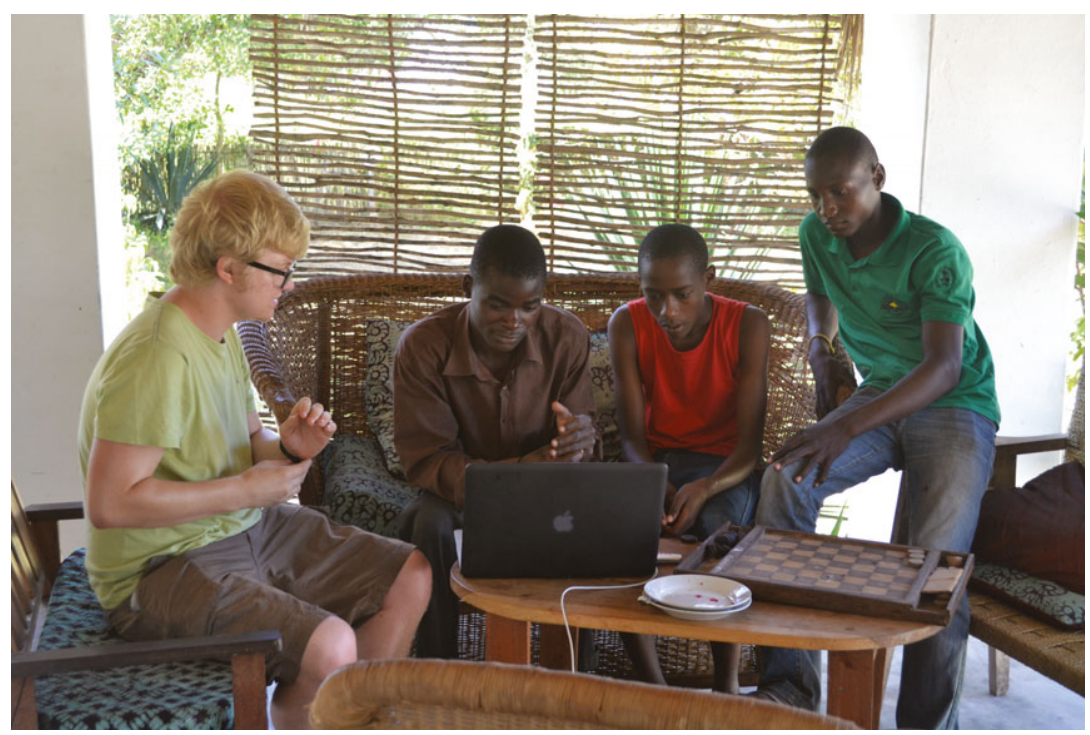

Figure 5. Learning Photoshop

considered. Recent literature warns that Western students can 'inappropriately take on roles of "expert" or "teacher" regardless of their experience or qualifications, this can be seen to represent the neo-colonial construction of the westerner as racially and culturally superior (Raymond \& Hall 2008, 531).

It requires a degree of intercultural competency to counter preconceived stereotypes that might be carried over from our own culture, albeit unintentionally. This is the 'cultural essentialism' that Crouch (2000) warns of, that can stultify cultural development. Yet 'Culture is never just a matter of ownership, of borrowing and lending with absolute debtors and creditors, but rather of appropriations, common experiences, and interdependencies of all kinds among different cultures' (Said 1994, 262).

\section{Intercultural competencies}

On departure there was a mix of emotions: apprehension, nervousness and excitement. For one student it felt 'surreal' after months of anticipation and preparation. They were all looking forward to the immersive experience of a different culture, environment, climate and meeting the people of Mozambique, and as such one student was prepared for 'a life changing experience'.

It is not only being able to deal with psychological stress, but also developing communication skills that are central to intercultural competency (Root \& Ngampornchai 2013). The students hoped to make new friends, once they returned they expected to have a better appreciation for what they had, and an improved ability to respond creatively to different circumstances and change.

In Mozambique the students appreciated the relaxed attitude they found amongst the Mozambican people, which helped to alleviate the stress of being immersed in such a different country. Despite the poverty and the health risks associated with a tropical country, the students were 'humbled' by the positive and friendly attitude they found in the people of Mossuril. Groups of inquisitive children watched the students paint the murals and in the town it attracted broader interest from passers by (see Figure 6). Other shop owners saw the popular interest and through the intercession of the NGO lobbied for murals on their walls to advertise the film festival.

There were other interactions in the form of football matches, performances with a local drumming troupe and an invitation to a local wedding. 'They show a real sense of community' (Student M). This does not suggest that the UK students were surprised that a community spirit might exist in Mossuril; rather it was a revelation to see the value of a community and what may be lacking in the UK. 


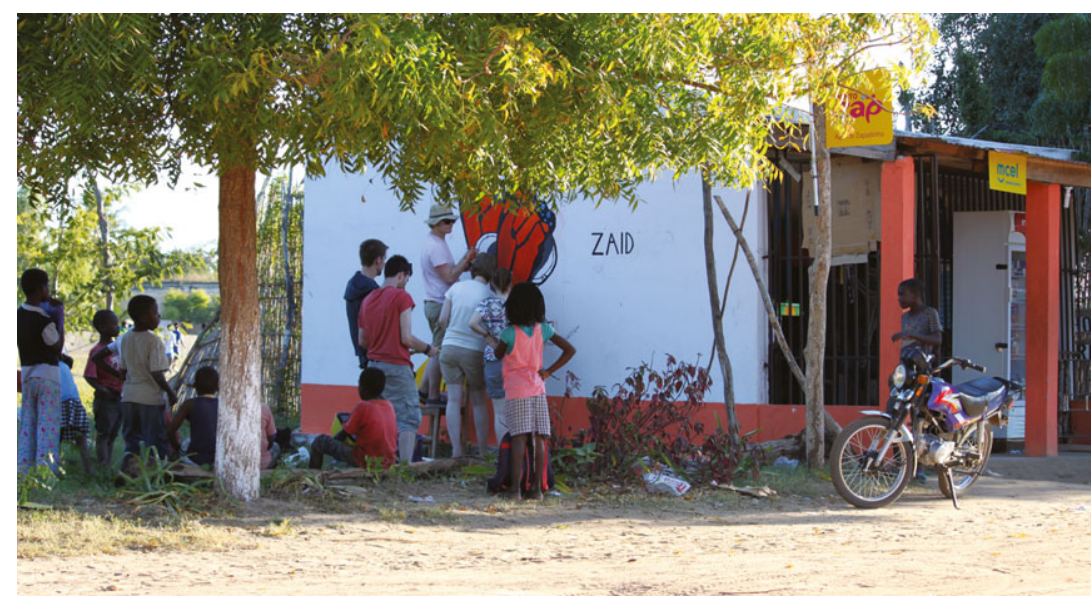

Figure 6. Children watch the mural painting

Through the intercultural experience they 'learnt the art of diplomacy' and how to be flexible - it 'challenged my thinking of preconceived ideas' (Student J). 'It's matured me, I've overcome things you don't get a chance to tackle in the UK' (Student E).

As they reflected on their UK lives, the simple expectations of clean running water and a fridge containing fresh food were now seen as precious commodities. One student overcame an obsessive eating disorder (Student S). 'My perception of Africa was so naïve ... it's such a cliché to say that "travel broadens the mind" but it's true. It makes you realise how blissfully ignorant your life can be' (Student R).

The material differences clearly had an immediate physical impact on the students, but the cultural differences have continued to resonate months after. Developing intercultural competency takes time and critical reflection of ones' own cultural identity. It is difficult, but necessary to address cultural naivety. As Said $(1994,336)$ argues:

It is more rewarding - and more difficult - to think concretely and sympathetically, contrapuntally, about others than only about 'us.' But this also means not trying to rule others, not trying to classify them or put them in hierarchies, above all, not constantly reiterating how 'our' culture or country is number one (or not number one, for that matter).

Global consumerism has changed the way otherness is viewed in foreign cultures. Brand imperialism has invaded Mozambique in the form of telecommunications and soft drinks corporations. The simplest mode of communication is employed to paint Vodafone and Coke brand marques that cover entire walls of traditional mud constructed homes in villages, as well as concrete urban walls that are ubiquitous the world over.

\section{Critical approaches to global consumerism}

In the context of their studies the students were looking forward to 're-evaluating what design could be', working with craft materials and witnessing the impact of their work in action in the community. Their learning would be given a new dimension, perspective and way of looking at materials and communication where digital technology and first world resources were less easily accessed. A degree of economic poverty was expected, if only informed by Western media, but none (lecturers included) were prepared for the far more complex overlap of technologies, cultures, commercial and political relationships that Mozambique shares with the outside world.

Returning from Mozambique there was a lot to absorb and reflect on: 'I'm still processing it, there's a lot going on in my mind' (Student E). Possessions and the value of family were re-evaluated. 'The locals, most 
of whom had so little in terms of material possessions, were in many ways happier than ourselves in the West ... I am able to take more moments to pause and simply appreciate what I have' (Student M).

This research does not wish to undervalue the significance of a Western student recognising the good fortune of their place of birth, but as in previous studies, it is essential for students to question rather than reinforce the stereotypes that assume local people accept their poverty (Raymond \& Hall 2008; Sin 2009).

The students' awareness of their material wealth problematically juxtaposes their superiority when compared to the Mozambicans (Raymond \& Hall 2008). Previous studies of volunteer tourism have found that their 'act of giving relieves (the) guilt of being in a superior position, but does not in any way change the system of privileges available to (volunteer) and not available to the aid-recipients' (Sin 2009, 495). In order to counter such dichotomies, a deeper cultural understanding of the host aid-recipient is essential. This project fostered collaboration and an exchange of skills and knowledge; it had recipients on both sides. At the same time the UK students were witness to the social reality of economic inequality and hardship, particularly amongst younger children. An invaluable political and social historical context was provided by Teran (2007), which was essential in cementing the value of the intercultural experience for all the students, UK and Mozambican.

\section{Students that remained at home}

From the outset of the briefs that were given to the cohort of thirty students, there was a keen sense of involvement. They were sceptical at first - were the projects live? Seeing the winning design work used in a crowdfunding campaign accompanied by the stories and films about the local community changed this. From this point forward they were all very keen to follow progress.

All participants read the liveblog and commented on the amount of writing produced, more familiar with short form messaging by text and Tweet, it was the most writing they had ever seen from their fellow students. One wrote: 'They all had a lot to talk about, so we felt we should read it I learned a lot from it, seeing the way graphics were being used - it changed my mind about graphics completely. The day you posted the picture of the boat sail with the butterfly (see Figure 3), I nearly started to cry' (Home Student 1). It was a surprise to them that their peers would be so actively engaged with local Mozambican students. This authentic immersion promoted interculturalism: 'I would have liked to do that' (Home Student 2). The student experience was shared online: 'it really made me want to have an opportunity like that, every time I read the blog I felt that a bit more' (Home Student 3).

Not only promoting interculturalism, but the critical approach to global consumerism using graphic design as a force for social change was also appreciated: 'It just looked like a huge adventure, yet at the heart of it all, there was the branding projects that our class had done - I suppose without the branding, there may not have been a film festival - I really began to see how graphic design can make something exist in the first place' (Home Student 4).

Five students experienced Mozambique - however, others felt part of it. Their perception of what graphic design can be changed dramatically: 'Even if it was just for a short time when I finish University, I would like to see if I could use my skills in this way - make a difference with graphics' (Home Student 2).

Graphic design education has always been primarily a vocational and practice-led subject, providing the creative industries with a ready-made workforce. An international social project, such as this one in Mozambique, can have a profound effect on the aspirations of all students that are involved, even those that remain at home. 'I have been focused on getting a job in a big branding agency - I'm re-evaluating that now' (Home Student 5). Horizons are opened up to previously unimagined possibilities.

Did the home students develop intercultural competencies? Perhaps it only raised their awareness, but it did prove the power of design advocacy and sow a desire to explore other cultures, and hopefully foster openness and tolerance. 


\section{Conclusion}

This research reveals how an international project combined with graphic design advocacy can have an educational and cultural impact locally and globally.

It is clear that the time the UK students spent in Mozambique has had a dramatic impact on the visibility of the NGO's work, and also on the lives of the students.

The UK students have returned to their studies and we will watch to see how fearless and experimental they are in practice, after having spoken with such conviction about the inspiration they have taken from Mozambique. Two months after the LIFE film festival the recalcitrant owner of the Mossuril internet café has already painted over his butterfly mural. Will others follow, or will the visible mark of these adventurous students slowly weather and decay in the tropical climate?

The long-term impact on the Mozambican community will only be guaranteed by sustained involvement of the NGOs and other educational interventions. The legacy of the project on the UK students will only be evident if they reflect deeply on their intercultural experience and how they approach global consumerism in their future design careers. As Said (1994) points out, it is difficult, but ultimately more rewarding not to think of hierarchies when comparing our culture with others, but to view them as complex layers of geography, images, languages and imaginings. Despite a transformation of participation amongst the European and African students there is some way to go before an even relationship within a community of learners exists.

Risk taking, experimentation and an appetite for enquiry are attributes that students are encouraged to develop, but they can equally apply to teachers and lecturers as they develop their curriculum. Within the framework of university learning, teaching and assessment strategies space can be found for design educators to look beyond corporate and conventional consumer outlets to a more socially conscious and community focus without borders.

While Cahalan (2007), McCoy (1994) and Rawsthorn (2013) argue that graphic design can foster intercultural links and help the disadvantaged; we would posit that this would apply equally to all design disciplines. As higher education institutions seek to develop meaningful internationalism, Design is well placed to combine forces with charities and NGOs that are seeking energetic, problem solving young creatives who wish to improve the world as global citizens.

This project shows that design education can develop intercultural competencies using critical approaches to global consumerism. The wider impact is also positive on those students remaining in the home country, as they can see the value of design in a different context where it is not purely corporately driven or trivialised, but radicalised to challenge the global consumerist hegemony, providing economic, ecological or cultural empowerment on a local and global stage. Students and teaching staff across all disciplines can begin to open their eyes to wider opportunities for social change and global citizenship. Design can make a difference.

Iain Macdonald is an Associate Professor in Graphic Design and Creative Advertising at Edinburgh Napier University. He has over 20 years of creative industry experience as an award winning television graphic designer at BBC Television, and as a film and commercials director. His focus is on practice-led research and pedagogic research into internationalisation, the moving image and lens-based media, forming an argument for future directions in art and design practice. Contact address: Edinburgh Napier University, School of Arts \& Creative Industries, 219 Colinton Rd, Edinburgh EH14 1DJ, United Kingdom. Email: i.macdonald@napier.ac.uk

Myrna MacLeod is a Senior Lecturer and Programme Leader for the award winning BDes Graphic Design course at Edinburgh Napier University. She worked as a graphic designer in the USA, London and Scotland. Her research interests focus on citizen design, graphic advocacy and the poster culture in Scotland. Contact address: Edinburgh Napier University, School of Arts \& Creative Industries, 219 Colinton Rd, Edinburgh EH14 1DJEdinburgh, United Kingdom. Email: m.macleod@napier.ac.uk 


\section{References}

Anderson, B. (1991) Imagined Communities, revised edn. London and New York: Verso.

Brooks, R. \& Waters, J. (2011) Student Mobilities, Migration and the Internationalization of Higher Education. Basingstoke: Palgrave Macmillan.

Brown, J. S., Collins, A. \& Duguid, P. (1989) Situated cognition and the culture of learning, Educational Researcher, Vol. 18, No. 1, pp. 32-42.

Bryant, J., Matthews, G. \& Walton, G. (2009) Academic libraries and social and learning space: a case study of Loughborough University Library, UK, Journal of Librarianship and Information Science, Vol. 41, No. 1, pp. 7-18.

Cahalan, A. (2007) The Future of Design (online). Available at: http://education.agda.com.au/articles/view/story/ Education, AGDA, 1 February. the-future-of-design-education (accessed 10 April 2015).

Crouch, C. (2000) Negotiating cross-cultural education in the visual arts, Journal of Art \& Design Education, Vol. 19, No. 3, pp. $297-303$.

Deardorff, D. K. (2009) Intercultural Competence. Thousand Oaks, CA: Sage.

Flick, U. (2014) An Introduction to Qualitative Research. London: Sage.

Garland, K. (1964) First Things First Manifesto. London: privately published.

Goode, M. L. (2008) The role of faculty study abroad directors: a case study, Frontiers: The Interdisciplinary Journal of Study Abroad, Vol. 15, pp. 149-72.

HEA (2008) A Changing World: the Internationalisation Experiences of Staff and Students (Home and International) in UK Higher Education (online). Available at: https://www.heacademy.ac.uk/system/files/5248.pdf (accessed 19 August 2016).

Hyland, F., Trahar, S., Anderson, J. \& Dickens, A. (2008) A Changing World: The Internationalisation Experiences of Staff and Students (Home and International) in UK Higher Education. Higher Education Academy (online). Available at: http://escalate.ac.uk/downloads/5248.pdf (accessed 15 September 2014).

Knoblauch, H., Tuma, R. \& Schnettler, B. (2013) Video analysis and videography, The Sage Handbook of Qualitative Data Analysis. London: Sage, pp. 435-49.

Loo, R. \& Thorpe, K. (2002) Using reflective learning journals to improve individual and team performance, Team Performance Management, Vol. 8, No. 5, pp. 134-9.

Macbeth, A. (2014) Five Go to Mozambique (online). Available at: http://fivegotomozambique.blogspot.co.uk/2014/06/alex-macbethdirector-of-mossuril-film.html (accessed 19 August 2016).

McCoy, K. (1994) Countering the tradition of the apolitical designer, in J. Myerson [Ed.] Design Renaissance: Selected Papers from the International Design Congress Glasgow, Scotland 1993. Horsham: Open Eye, pp. 105-14.

Mendoza, H. R. \& Matyók, T. (2013) Designing student citizenship: internationalised education in transformative disciplines, International Journal of Art \& Design Education, Vol. 32, No. 2, pp. 215-25.

Mertens, D. M. (2005) Research Methods in Education and Psychology: Integrating Diversity with Quantitative and Qualitative Approaches, second edn. Thousand Oaks, CA: Sage.

NSEAD (2014) A Manifesto for Art, Craft and Design Education (online). Available at: http://www.nsead.org/downloads/NSEADManifesto-2014.pdf (accessed 12 December 2014).

Ortlipp, M. (2008) Keeping and using reflective journals in the qualitative research process, The Qualitative Report, Vol. 13, No. 4, pp. 695-705.

Papoutsaki, E. (2006) De-Westernising Research Methodologies: Alternative Approaches to Research for Higher Education Curricula in Developing Countries. Paper presented at the Global Colloquium of the UNESCO Forum on Higher Education, Research \& Knowledge, Paris, November 29 - December 1 (online). Available at: http://portal.unesco.org/education/en/files/51671/ 11634968135PapoutsakiEN.pdf/Papoutsaki-EN.pdf (accessed 10 January 2016).

Poynor, R. (1999) First Things First: a brief history, Adbusters, No. 27, pp. 54-6.

Raymond, E. M. \& Hall, C. M. (2008) The development of cross-cultural (mis) understanding through volunteer tourism, Journal of Sustainable Tourism, Vol. 16, No. 5, pp. 530-43.

Rawsthorn, A. (2013) Hello World: Where Design Meets Life. London: Penguin.

Rizvi, F. (2004) Debating globalization and education after September 11, Comparative Education, Vol. 40, No. 2, pp. $157-71$.

Root, E. \& Ngampornchai, A. (2013) 'I came back as a new human being': student descriptions of intercultural competence acquired through education abroad experience, Journal of Studies in International Education, Vol. 17, No. 5, pp. 515-32.

Said, E. (1994) Culture and Imperialism. London: Virago.

Sin, H. L. (2009) Volunteer tourism - 'involve me and I will learn'?, Annals of Tourism Research, Vol. 36, No. 3, pp. 480-501.

Steers, J. (2009) Creativity: delusions, realities, opportunities and challenges, International Journal of Art \& Design Education, Vol. 28, No. 2, pp. 126-38.

Teran, L. (2007) Mozambique Mysteries. London: Virago Press.

Wagner, Z. M. (2006) Using student journals for course evaluation, Assessment and Evaluation in Higher Education, Vol. 24, No. 3, pp. 261-72.

Waters, J., Brooks, R. \& Pimlott-Wilson, H. (2011) Youthful escapes? British students, overseas education and the pursuit of happiness, Social \& Cultural Geography, Vol. 12, No. 5, pp. 455-69. 